\title{
Konstruksi Citra Anggota Komunitas Virtual pada Bigo Live
}

\author{
Aftri Mardianti Fitria ${ }^{1}$ dan Arie Prasetio ${ }^{2}$ \\ ${ }^{1,2}$ Universitas Telkom
}

\begin{abstract}
ABSTRAK
Media sosial terus berkembang membuat interaksi di ruang siber semakin terasa nyata dengan perkembangan fitur yang disediakan oleh media sosial. Bigo Live merupakan media sosial yang muncul di Indonesia pada tanggal 1 Juni 2016 dengan konten live video streaming. Media sosial ini menjadi lebih banyak diminati karena penggunanya dapat mendapatkan penghasilan dari melakukan live. Interaksi sosial yang terjadi di Bigo Live memunculkan fenomena terbentuknya komunitas virtual, salah satunya adalah komunitas virtual KCM (Keluarga Cemara). Jenis penelitian ini menggunakan metode etnografi virtual dengan pendekatan kualitatif. Data diperoleh melalui wawancara dan observasi yang dilakukan secara online maupun offline. Informan dalam penelitian ini berjumlah enam orang yang terdiri dari lima anggota KCM dan satu orang konsultan media digital. Tujuan dari penelitian ini adalah untuk mengetahui bagaimana motif, interaksi sosial, dan proses pengelolaan kesan dalam komunitas virtual berdasarkan interaksi sosial yang dilakukan oleh pengguna media sosial Bigo Live. Hasil penelitian ini menunjukkan bagaimana motif pengguna Bigo Live yaitu ingin mencapai nilai sosial, nilai psikologis, dan nilai material. Interaksi sosial yang terjadi dalam komunitas virtual KCM di Bigo Live di dasari oleh faktor imitasi, faktor sugesti, dan faktor simpati di mana menghasilkan berbagai simbol yang dimaknai bersama sehingga menjadi dasar dalam melakukan interaksi sosial di Bigo Live yang membentuk citra anggota KCM. Tidak hanya itu, terdapat berbagai varietas bahasa yang muncul baik yang berasal dari perangkat maupun dari interaksi sosial yang terjadi di Bigo Live.
\end{abstract}

Kata-kata Kunci: Konstruksi citra; pengelolaan kesan; interaksi sosial; motif; varietas bahasa

\section{The Image Construction of Virtual Community Members in Bigo Live}

\begin{abstract}
Social media always grow make interaction in cyberspace feel more like in a real life with the development features provided by social media. Bigo Live launched in June, 1st 2016 with live video streaming content. This social media is becoming more popular because users can get money from doing live. The social interaction that occurs in the formation of Bigo Live rise to the phenomena of virtual communities, one of which is a virtual community of KCM (Keluarga Cemara). The research is a virtual ethnography approach ofqualitative. Data were obtained through interviews and observations made online or offline. Informants in this study of six people consisting of five members of KCM and one of digital media consultant. The purpose of this study is to find out how the motives, social interactions, and virtual community management process based on social interaction conducted by social media users Bigo Live. The results of this study show motif of Bigo Live users that aresocial value, psychological value, and material value. Social interactions in virtual community KCM in Bigo Live constituted by imitation factor, suggestion factor, and sympathy factor that isproduce different symbols along interpreted thus become the fundamental basis of do social interaction in Bigo Live and form the image of members KCM. In this study also found the emergence of language varieties of interactions made in Bigo Live.
\end{abstract}

Keywords: Image construction; impression management; social interaction; motif; new language

Korespondensi: Aftri Mardianti Fitria, S. I. Kom. Universitas Telkom. Jl. Telekomunikasi No. 01, Terusan Buah Batu, Sukapura, Dayeuhkolot, Bandung, Jawa Barat 40257.Email: aftrimardianti@gmail.com 


\section{PENDAHULUAN}

Media sosial terus berkembang membuat interaksi di ruang siber semakin terasa nyata dengan perkembangan fitur yang disediakan oleh media sosial. Bigo Live diluncurkan pertama kali pada bulan Maret 2016 di seluruh dunia. Di Indonesia, Bigo Live hadir dan diresmikan pada tanggal 1 Juni 2016. Bigo Live merupakan salah satu aplikasi media sosial yang memiliki fitur live video streaming dan video call, sehingga memudahkan penggunanya untuk melakukan interaksi dengan bertatap muka dan terasa lebih nyata. Bigo Live juga didukung dengan fitur yang dapat ditukarkan menjadi mata uang rupiah.

Interaksi sosial di Bigo Live yang terasa lebih nyata dan dilakukan secara berulang, membuat penggunanya merasa lebih dekat sehingga memunculkan berbagai perasaan serta nilai yang ingin dicapai secara bersamasama sesuai dengan motif penggunaan media sosial Bigo Live. Hal ini memunculkan fenomena komunitas virtual yang menjamur di Bigo Live. Salah satu komunitas virtual yang menarik untuk diteliti adalah komunitas KCM (Keluarga Cemara) yang dibentuk pada tanggal 18 Juli 2016 oleh 4 pengguna Bigo Live yang memiliki asa kekeluargaan dengan struktur, peraturan, serta visi dan misi yang jelas. KCM dibagi menjadi 3 tim sesuai dengan karakter anggotanya, yaitu tim $\mathrm{K}$, tim $\mathrm{C}$, dan tim $\mathrm{M}$. Masing-masing tim memiliki visi dan misi yang mendasari setiap anggota dalam melakukan interaksi sosial saat melakukan live. Sehingga terdapat proses pengelolaan kesan di mana setiap anggota berusaha menampilkan kesan sesuai dengan keinginannya dan membentuk citra di Bigo Live.

Pada dasarnya konstruksi citra adalah sebuah bangunan yang diinginkan oleh tahap konstruksi. Dimana bangunan konstruksi citra ini terbentuk dalam dua model, yang pertama adalah good news. Good news merupakan konstruksi yang cenderung mengkonstruksi suatu pemberitaan sebagai pemberitaan yang baik padahal model ini objek pemberitaannya sudah dikonstruksi sebagai suatu yang memiliki citra baik sehingga terkesan lebih baik dari sesungguhnya. Sedangkan yang kedua adalah bad news, yang merupakan sebuah konstruksi yang cenderung mengkontruksi kejelekan atau cenderung memberi citra jelek, lebih buruk dari sesungguhnya yang ada pada objek pemberitaan itu sendiri (Zuhdi, 2010).

Menurut Jefkin, citra adalah kesan seseorang atau individu tentang sesuatu yang muncul sebagai hasil dari pengetahuan dan pengalamannya (Soemirat \& Ardianto, 2007). Sedangkan menurut Rakhmat, citra didefinisikan sebagai gambaran tentang realitas di mana tidak harus sesuai dengan realitas, citra 
merupakan dunia menurut persepsi (Soemirat \& Ardianto, 2007). Dari dua pendapat menurut pakar tersebut, citra dapat diartikan sebagai kesan seseorang atau individu berdasarkan persepsi yang muncul dari adanya pengetahuan dan pengalaman.

Maryati dan Suryawati mengatakan bahwa interaksi sosial adalah kontak atau hubungan timbal balik atau interstimulasi dan respons antar individu, antar kelompok, atau antar individu dan kelompok (Anwar \& Adang, 2013). Interaksi tidak hanya berlangsung melalui gerak-gerak secara fisik saja, melainkan melalui lambang-lambang yang maknanya perlu dipahami (Effendy, 2001). Gillin dan Gillin mengatakan syarat-syarat yang perlu dipenuhi agar interaksi sosial itu mungkin terjadi adalah adanya kontak sosial dan adanya komunikasi (Anwar \& Adang, 2013).

Pada dasarnya, interaksionisme simbolik merupakan suatu aktivitas yang pasti dilakukan oleh setiap manusia saat melakukan proses pertukaran pesan dengan simbol (lambang) yang diberi makna. Simbol (lambang) merupakan media yang digunakan oleh seseorang untuk menyampaikan pikiran atau perasaannya kepada orang lain. Simbol dalam perspektif ini didefinisikan sebagai objek sosial yang digunakan untuk merepresentasikan apa pun yang disepakati untuk direpresentasikan. Simbol dapat berupa bahasa, isyarat, gambar, warna, dan lain sebagainya. Namun simbol dalam bentuk bahasalah yang paling banyak digunakan dalam proses komunikasi (Elbadiansyah, 2014).

Dramaturgi merupakan teori berdasarkan pandangan Erving Goffman di mana setiap individu dalam melakukan interaksi sosial yang terjadi dalam kehidupan sama dengan pertujukkan teater atau drama di atas panggung di mana terdapat panggung depan dan panggung belakang. Namun peneliti menambahkan panggung tengah menurut (Mulyana, 2008) untuk mengetahui proses pengelolaan kesan yang dilakukan. Yang berarti ketika seseorang berada di hadapan orang lain, individu/aktor tersebut akan melakukan berbagai kegiatan yang dapat menyampaikan kesan kepada orang yang diinginkan oleh individu tersebut yang dinamakan management impression oleh Goffman.

Teori inferensi koresponden juga disebut juga sebagai teori atribusi internal. Jones dan Davis mencoba menjelaskan kesimpulan (inference) pengamat tentang orang lain atau aktor dalam berbuat atau berperilaku. Dari analisis Heider, Jones dan Davis dalam proses menyimpulkan, memformulasikan perilaku pada karakteristik personal (disposisi) (Walgito, 2011).

Teori atribusi eksternal ini dikemukakan oleh Kelley. Kelley memusatkan pandangan teori ini pada pengamat bahwa atribut perilaku 
aktor disebabkan oleh keadaan lingkungan di mana aktor berinteraksi. Karena itu, analisis Kelley keluar dari kaidah sebab personal. Kelley mendefinisikan atribusi sebagai proses persepsi apa yang ada dalam lingkungan.

Motif merupakan sesuatu yang melingkupi semua penggerak, alasan, atau dorongan dalam diri manusia untuk berbuat sesuatu. Maka, menurut Martianah (1984) pada prinsipnya, motif adalah suatu konstruksi yang potensial dan laten, yang dibentuk oleh pengalaman, yang secara relatif dapat bertahan meskipun kemungkinan berubah masih ada, dan berfungsi menggerakkan serta mengarahkan perilaku ke tujuan tertentu (Arifin, 2015). Sedangkan menurut Schutz untuk membedakan tindakan seseorang dapat dibagi ke dalam dua fase, yaitu in-order-to-motive dan because-motive. Inorder-to-motive merujuk pada maksud, rencana, harapan, minat yang diharapkan aktor di masa depan. Sedangkan because-motive mengacu pada pengalaman masa lalu aktor dan tertanam dalam pengetahuannya yang terendapkan (preconstituted knowledge), ini disebut juga sebagai alasan atau sebab (Mulyana, 2008).

Rheingold (1993) yang mengatakan bahwa komunitas virtual merupakan agregasi sosial yang mengambil bentuk di dalam internet di mana semua orang membawa persoalan untuk didiskusikan dalam waktu yang lama, dan melibatkan perasaan/pemikiran penggunanya dengan relasi yang terbentuk di ruang siber (Nasrullah, 2015). Dilihat dari karakter, merujuk pada penjelasan Tonnies, bahwa komunitas virtual bisa terbagi menjadi Gemeinschaft dan Gesellschaft. Gemeinschaft merujuk pada jenis komunitas yang berkarakter 'total community' di mana setiap individu maupun aspek sosial di dalamnya berinteraksi secara vertikal maupun horizontal. Hasil dari adanya kesamaan maupun kehidupan, terbentuk dari adanya pertukaran ritual maupun simbol sebagaimana yang terjadi dalam interaksi sosial secara nyata yang dibangun secara face-to-face interactions. Adapun Gesellschaft menurut Kollock dan Smith (1999) merupakan kebalikan dari kondisi Gemeinschaft (Nasrullah, 2014).

\section{METODE PENELITIAN}

Metode penelitian yang digunakan adalah adalah metode kualitatif. Dimana menurut Sugiyono menyatakan bahwa penelitian kualitatif dilakukan dengan pendekatan partisipasi aktif melalui strategi yang bersifat interaktif dan fleksibel (Nugraha, Yustikasari, \& Koswara, 2017). Penelitian kualitatif ini secara spesifik lebih diarahkan untuk menggunakan metode studi Etnografi Virtual, yang menekankan kepada pendekatan dalam melihat realitas atau fenomena yang terjadi di cyberspace dalam dua aspek yaitu kultur dan juga artefak kultural (Hine, 2001). Peneliti 
ingin mengetahui bagaimana interaksi sosial yang terjalin dapat membentuk citra dalam komunitas virtual di Bigo Live, oleh karena itu peneliti memilih paradigma konstruktivisme agar peneliti mendapatkan pemahaman mengenai fakta-fakta proses interaksi sosial dari para pengguna Bigo Live yang tergabung dalam komunitas virtual dengan menjadikan komunitas virtual Bigo Live sebagai faktor sentral yang dapat membangun citra baru. Subjek dalam penelitian ini adalah pengguna media sosial Bigo Live yang tergabung dalam komunitas virtual. Sedangkan objek dalam penelitian ini adalah interaksi sosial komunitas virtual di media sosial Bigo Live.

\section{HASIL DAN PEMBAHASAN}

Perangkat Bigo Live mendukung penggunanya untuk dapat berinteraksi secara lebih nyata, apa lagi dengan fitur yang terus berkembang membuat penggunanya memiliki motif tersendiri dalam menggunakan Bigo Live. Motif merupakan sesuatu yang melingkupi semua penggerak, alasan, atau dorongan dalam diri manusia untuk berbuat sesuatu. Pada prinsipnya, motif menurut Martianah (1984) adalah suatu konstruksi yang potensial dan laten, yang dibentuk oleh pengalaman, yang secara relatif dapat bertahan meskipun kemungkinan berubah masih ada, dan berfungsi menggerakkan serta mengarahkan perilaku ke tujuan tertentu (Arifin, 2015). Dalam penelitian ini peneliti menggunakan komunitas virtual KCM sebagai subjek. Sedangkan informan yang dipilih terdiri dari 5 orang yang sudah lama menggunakan Bigo Live dan sudah cukup lama bergabung dengan KCM. Tidak hanya itu, peneliti juga menggunakan informan pendukung yang merupakan seorang konsultan media digital untuk melengkapi perspektif dari seseorang yang ahli dalam bidangnya.

Menurut Nasrullah yang merupakan seorang digital consultant, pendorong seseorang untuk berinteraksi di media sosial terkait dengan Bigo Live yaitu yang pertama karena ingin mencoba. Bigo Live merupakan media sosial baru sehingga banyak yang penasaran dan ingin mencoba. Yang kedua, eksistensi, yang berarti orang tersebut memiliki kemampuan untuk bersosial. Yang ketiga, karena sistem perangkat Bigo Live yang dapat memberikan manfaat ketika seseorang mencobanya, yaitu perangkat yang dapat memberikan yang kemudian tersebut bisa ditukarkan dengan uang. Hal tersebut yang menyebabkan broadcaster/host melakukan berbagai cara agar bisa mendapatkan dari viewers-nya.

Jika dikaitkan antara teori dan hasil penelitian yang telah peneliti dapatkan dari wawancara dan observasi yang sudah dilakukan, maka peneliti menganalisis bahwa motif kelima informan sesuai dengan pendapat 
menurut Schutz. Schutz membedakan tindakan seseorang ke dalam dua fase, yaitu in-orderto-motive merujuk pada maksud, rencana, harapan, minat yang diharapkan aktor di masa depan. Sedangkan because-motive mengacu pada pengalaman masa lalu aktor dan tertanam dalam pengetahuannya yang terendapkan (preconstituted knowledge), ini disebut juga sebagai alasan atau sebab (Mulyana, 2008). Motif kelima informan menggunakan Bigo Live menurut analisis peneliti adalah karena banyaknya waktu menganggur sehingga ingin mendapatkan uang dari Bigo Live; kurang percaya diri dan malu dalam berkomunikasi di depan orang banyak sehingga ingin meningkatkan kepercayaan diri dengan menambah teman dan meningkatkan eksistensi; kurang berinteraksi dengan orang lain sehingga ingin mencari teman baru, masa lalu yang kurang bersosialisasi sehingga ingin menambah teman, memperluas network dan mencari relasi dalam segala hal; dan tidak memiliki orang yang tepat untuk bercerita sehingga ingin menyalurkan kesedihan maupun kebahagiaannya di Bigo Live. Tidak hanya itu, kelima informan tersebut memiliki kemampuan dalam berkomunikasi serta keinginan untuk bersosialisasi.

Dengan mengetahui pengetahuan dan kemampuan serta tujuan dari kelima informan dalam menggunakan Bigo Live, peneliti menganalisis bahwa perilaku kelima informan merupakan atribut personal atau karakteristik personal. Hal ini sesuai dengan teori inferensi koresponden yang disebut juga dengan teori atribusi internal. Jones dan Davis mencoba menjelaskan kesimpulan (inference) pengamat tentang orang lain atau aktor dalam berbuat atau berperilaku. Dari analisis Heider, Jones dan Davis dalam proses menyimpulkan, memformulasikan perilaku pada karakteristik personal (disposisi) (Walgito, 2011).

Komunitas virtual KCM terbentuk karena adanya interaksi yang dilakukan secara berulang kali dalam suatu room pengguna Bigo Live, di mana interaksi yang terjadi menimbulkan kesamaan cara pandang dan perasaan yang mendukung keinginan untuk lebih mendekatkan diri antara satu pengguna dengan pengguna lainnya serta adanya kesamaan nilai yang ingin dicapai, yaitu nilai sosial, nilai psikologis, dan nilai material, namun didasari oleh hubungan kekeluargaan. Hal ini sesuai dengan teori komunitas virtual menurut Rheingold yang mengatakan komunitas virtual dibentuk dari bertemunya para pengguna internet dalam waktu yang lama dan seiring dengan perjalanan waktu interaksi ini memunculkan semacam "rasa" di antara para penggunanya (Nasrullah, 2014).

Terjadinya komunitas virtual KCM sudah sesuai dengan syarat terjadinya komunitas virtual menurut Catoni dan Tardini, di mana 
Bigo Live dan grup Line merupakan tempat terjadinya interaksi dan komunikasi, relasi antar anggota terjadi dan dikelola secara, seluruh anggota yang memiliki rasa kepemilikan yang ditandai dengan adanya lambang KCM dalam username Bigo Live, adanya struktur internal dalam KCM, dan adanya ruang simbolik yang saling berbagi di Bigo Live maupun grup Line yang direpresentasikan dengan adanya peraturan dan visi dan misi yang jelas di KCM.

KCM memiliki struktur yang jelas di mana setiap anggotanya dapat saling berinteraksi secara vertikal maupun horizontal yang dilakukan setiap hari dan terbilang sudah cukup lama sehingga terdapat keterikatan dan hubungan yang lebih mendalam antar satu anggota dengan anggota lainnya yang sering melakukan interaksi. Hal ini merupakan karakter yang merujuk pada penjelasan Tonnies di mana komunitas virtual terbagi menjadi Gemeinschaft dan Gesellschaft. Karakteristik KCM termasuk dalam Gemeinschaft yang merujuk pada jenis komunitas yang berkarakter 'total community' di mana setiap individu maupun aspek sosial di dalamnya berinteraksi secara vertikal maupun horizontal. Menurut Kollock dan Smith berjalan secara stabil dan dalam waktu yang lama, merupakan hasil dari adanya kesamaan maupun kehidupan, terbentuk dari adanya pertukaran ritual maupun simbol sebagaimana yang terjadi dalam interaksi sosial secara nyata yang dibangun secara face-to-face interactions (Nasrullah, 2014).

Perilaku yang dilakukan anggota $\mathrm{KCM}$ mayoritas merupakan perilaku yang seperti konsensus umum, hanya dilakukan di Bigo Live, serta tidak melakukan tindakan yang sama pada waktu dan situasi berbeda. Sehingga terbentuknya komunitas virtual $\mathrm{KCM}$ berasal dari faktor eksternal atau lingkungan seperti teori atribusi eksternal menurut Kelley yang memusatkan pandangan teori ini pada pengamat bahwa atribut perilaku aktor disebabkan oleh keadaan lingkungan di mana aktor berinteraksi. Media sosial Bigo Live merupakan media yang digunakan individu yang berada dalam ruang siber untuk melakukan interaksi sosial. Maryati dan Suryawati mengatakan bahwa interaksi sosial adalah kontak atau hubungan timbal balik atau interstimulasi dan respons antar individu, antar kelompok, atau antar individu dan kelompok (Anwar \& Adang, 2013). Interaksi tidak hanya berlangsung melalui gerak-gerak secara fisik saja, melainkan melalui lambang-lambang yang maknanya perlu dipahami (Effendy, 2001). Dari penjelasan mengenai interaksi sosial tersebut, kontak atau hubungan timbal balik yang terjadi antar anggota $\mathrm{KCM}$ maupun antar pengguna Bigo Live merupakan sebuah interaksi sosial. Syarat terjadinya interaksi sosial adalah adanya kontak sosial yang dapat berlangsung dalam 
tiga bentuk yaitu antar individu, antarindividu dengan kelompok, dan antarkelompok, serta adanya komunikasi yaitu seseorang memberi arti pada perilaku orang lain (Anwar \& Adang, 2013).

Dari pengamatan peneliti, pengguna Bigo Live memulai kontak sosial dengan memberikan 'tap donat/tap love' memberikan sapaan seperti 'halo' sehingga menyadari keberadaan viewers tersebut. pun membalas sapaan viewers, jika tidak mengenalnya, maka akan membuka profile viewers dan melihat info yang tertera di profil tersebut, seperti location, foto, dan lain sebagainya, sehingga komunikasi mereka pun bisa lebih memanjang dengan menanyakan berbagai hal. Fakta tersebut sejalan dengan hasil penelitian dari bahwa adanya respons kognitif pada followers suatu media sosial (seperti Instagram) yaitu untuk mendapatkan mendapatkan informasi dan manfaat yang lengkap tentang pesan yang diinginkan di suatu kota dengan postingan yang dikemas secara menarik dan menggugah rasa emosional (Ayutiani, Primadani, \& Putri, 2018).

Awal kemunculannya, perangkat Bigo Live terus berkembang dengan penambahan fitur maupun perubahan konten serta tampilan room sesuai dengan event yang sedang berlangsung di Bigo Live, di mana hal tersebut memengaruhi interaksi sosial yang terjadi di Bigo Live khususnya komunitas virtual KCM. Setiap pengguna akan berusaha menampilkan konten yang menarik agar viewersbetah berada dalam room tersebut dan mau memberikan . Perangkat Bigo Live memunculkan berbagai simbol berupa bahasa yang khas, di mana simbol tersebut memiliki makna yang disepakati bersama sesuai dengan teori interaksi simbolik. Interaksi simbolik merupakan suatu aktivitas yang pasti dilakukan oleh setiap manusia saat melakukan proses pertukaran pesan dengan simbol (lambang) yang diberi makna. Simbol (lambang) merupakan media yang digunakan oleh seseorang untuk menyampaikan pikiran atau perasaannya kepada orang lain. Simbol dalam perspektif ini didefinisikan sebagai objek sosial yang digunakan untuk merepresentasikan apa pun yang disepakati untuk direpresentasikan. Simbol dapat berupa bahasa, isyarat, gambar, warna, dan lain sebagainya. Namun simbol dalam bentuk bahasalah yang paling banyak digunakan dalam proses komunikasi (Elbadiansyah, 2014). Interaksi sosial yang terjadi di Bigo Live juga memunculkan varietas bahasa yang khas dan tidak ditemui di media sosial lainnya. Bahasa tersebut mayoritas merupakan bahasa yang digunakan dan dibentuk oleh lady boy, karena pengguna dengan karakter lady boy cukup banyak ditemukan di Bigo Live. Bahasa-bahasa tersebut muncul karena interaksi sosial yang dilakukan secara terus menerus dan pengguna- 
Tabel 1 Bahasa yang Muncul dari Perangkat Bigo Live

\begin{tabular}{|c|c|c|}
\hline No. & Perangkat & Makna \\
\hline 1 & $\begin{array}{l}\text { Broadcaster/ } \\
\text { Host }\end{array}$ & $\begin{array}{l}\text { Pengguna Bigo Live yang melakukan live broadcast dan memberikan } \\
\text { konten kepada viewers-nya. }\end{array}$ \\
\hline 2 & Beans & $\begin{array}{l}\text { Angka yang menunjukkan hasil dari pendapatan gift yang diberikan oleh } \\
\text { pengguna lain (penonton) }\end{array}$ \\
\hline 3 & Gift & $\begin{array}{l}\text { Tampilan hadiah yang diberikan oleh pengguna lain (penonton) kepa- } \\
\text { da host/broadcaster. Hadiah ini banyak macamnya, dan gift yang ter- } \\
\text { sedia dalam icon gift dapat berubah sesuai dengan event yang sedang } \\
\text { berlangsung di Bigo Live. }\end{array}$ \\
\hline 4 & Flying text & $\begin{array}{l}\text { Komen yang memiliki posisi lebih tinggi dibandingkan komen-komen } \\
\text { yang biasa, dilakukan oleh viewers jika komennya ingin lebih mudah } \\
\text { dibaca oleh host/broadcaster. }\end{array}$ \\
\hline 5 & Gift Icon & $\begin{array}{l}\text { Icon untuk memberikan gift (hadiah) kepada host/broadcaster. Gift terdi- } \\
\text { ri dari berbagai macam icon dengan berbagai diamonds yang dibutuhkan } \\
\text { untuk bisa mengirimkannya kepada broadcaster, seperti: treasure box } \\
\text { yang membutuhkan } 5000 \text { diamonds, roadstar yang membutuhkan } 3000 \\
\text { diamonds, maupun flower dan beer yang membutuhkan } 1 \text { diamond. Had- } \\
\text { iah ini banyak macamnya, dan gift yang tersedia dalam icon gift dapat } \\
\text { berubah sesuai dengan event yang sedang berlangsung di Bigo Live. }\end{array}$ \\
\hline 6 & $\begin{array}{l}\text { Tap Donat/Tap } \\
\text { Love }\end{array}$ & $\begin{array}{l}\text { Mengetuk layar smartphone yang menandakan keberadaan atau kesu- } \\
\text { kaan viewers pada broadcaster. Biasanya broadcaster yang meminta un- } \\
\text { tuk melakukan tap donat akan memperagakan dengan gaya 'mengetuk } \\
\text { layar smartphone' berkali-kali dan mengatakan 'yuk sambil tap donat'. } \\
\text { Semakin banyak viewers yang memberikan tap donat/tap love, maka } \\
\text { akan memungkinkan broadcaster berada di layar Home paling atas, seh- } \\
\text { ingga memudahkan pengguna lain untuk bisa masuk dalam roombroad- } \\
\text { caster tersebut. }\end{array}$ \\
\hline 7 & Video Call & $\begin{array}{l}\text { Akun kedua yang dapat melakukan live, berinteraksi dengan broadcast- } \\
\text { er, dan ditonton oleh viewers lain. }\end{array}$ \\
\hline 8 & Income & Pendapatan beans dari hasil live broadcast. \\
\hline 9 & Diamonds & $\begin{array}{l}\text { Harta dalam Bigo Live yang dimiliki oleh pengguna jika ingin melaku- } \\
\text { kan interaksi dengan broadcaster seperti: memberikan gift dan mengirim } \\
\text { flying text. }\end{array}$ \\
\hline 10 & Level & $\begin{array}{l}\text { Tingkatan pengguna dilihat dari intensitas pengguna berinteraksi dengan } \\
\text { broadcaster, atau melakukan live broadcast. }\end{array}$ \\
\hline 11 & Top Fans & Viewers yang paling banyak memberikan gift kepada broadcaster. \\
\hline
\end{tabular}

Sumber: Hasil Penelitian, 2017 
Tabel 2 Bahasa yang Muncul dari Interaksi Sosial di Bigo Live

\begin{tabular}{|c|c|c|}
\hline No & Bahasa & Makna \\
\hline 1 & $\begin{array}{l}\text { Bukan lagi } \\
\text { atau buk- } \\
\text { buklaglag }\end{array}$ & $\begin{array}{l}\text { Menandakan sesuatu yang luar biasa, contohnya ketika seseorang berkomentar 'pasti jamnya } \\
\text { beli di Amerika deh', maka komentar tersebut bisa dibalas dengan 'euh bukan lagi' atau 'buk- } \\
\text { buklaglag say' yang diucapkan dengan nada yang khas. Bahasa ini paling banyak digunakan } \\
\text { oleh seluruh broadcaster untuk menanggapi berbagai komentar maupun celaan dari viewers yang } \\
\text { menjadi budaya dalam Bigo Live. }\end{array}$ \\
\hline 2 & Menter & $\begin{array}{l}\text { Memiliki arti mewah. Biasanya menter dikatakan dengan kata yang memanjang dibelakang dan } \\
\text { dibarengi dengan kata 'bukan lagi' sehingga menjadi 'menteeeeer, bukan lagi..'. Menter muncul } \\
\text { karena Bigo Live dapat memperlihatkan kemewahan viewers yang ditandai dengan tingginya } \\
\text { jumlah gift yang diberikan, maupun broadcaster yang memperlihatkan kemewahan hidupnya } \\
\text { saat melakukan live broadcast. }\end{array}$ \\
\hline 3 & Syontok & $\begin{array}{l}\text { Memiliki arti mematuk. Biasanya broadcaster mengatakan kata "syontok nieee" sambil memper- } \\
\text { agakan gaya mematuk. Bahasa ini muncul dari latar belakang pengguna lady boy yang memiliki } \\
\text { banyak kosa kata. }\end{array}$ \\
\hline 4 & Coya & $\begin{array}{l}\text { Memiliki arti amit-amit, namun pengguna Bigo Live biasanya menggunakan coya sebagai kata } \\
\text { pelengkap dari amit-amit, sehingga yang dikatakan menjadi 'amit-amit coyaaa'. Bahasa ini juga } \\
\text { berasal dari latar belakang pengguna lady boy yang banyak memunculkan berbagai kosa kata } \\
\text { baru di dunia Bigo Live. }\end{array}$ \\
\hline 5 & Gila gila & $\begin{array}{l}\text { Kata ganti 'yakali' yang memiliki arti sama dengan 'masa iya' atau sesuatu yang dianggap 'wah'. } \\
\text { Dikatakan dengan speed berbicara yang cepat dan kata akhir yang berintonasi tinggi. }\end{array}$ \\
\hline 6 & Sawer & $\begin{array}{l}\text { Memberikan gift pada host/broadcaster. Biasanya diucapkan broadcaster yang meminta view- } \\
\text { ers untuk memberikannya gift jika viewers ingin meminta broadcaster melakukan sesuatu. Kata } \\
\text { sawer muncul karena adanya fitur Bigo Live berupa gift, diamonds, maupun beans yang menjadi } \\
\text { alat tukar menukar uang di Bigo Live. }\end{array}$ \\
\hline 7 & 777 & $\begin{array}{l}\text { Memiliki arti setuju yang identik dengan arti 'buka'. Biasanya diberikan kepada broadcaster } \\
\text { wanita yang terlihat menggoda. Bahasa ini muncul karena banyaknya pengguna wanita yang } \\
\text { menggoda agar viewers mau memberikan gift kepadanya. }\end{array}$ \\
\hline 8 & Toyong & $\begin{array}{l}\text { Sama artinya dengan 'sayang' biasanya diucapkan menggunakan tambahan kata diawal menjadi } \\
\text { 'uuu toooyongg' dengan nada yang khas. Bahasa ini muncul karena banyaknya pengguna yang } \\
\text { ingin terlihat manja dan terasa dekat dengan pengguna lainnya. }\end{array}$ \\
\hline 9 & Room & Ruang host/broadcaster dalam melakukan live. \\
\hline 10 & Live & Kegiatan menjadi host di Bigo Live. \\
\hline 11 & Raja Sawer & $\begin{array}{l}\text { Sebutan untuk orang-orang yang sering memberikan gift dalam jumlah yang sangat besar. Baha- } \\
\text { sa ini muncul karena fitur dalam perangkat Bigo Live yang memungkin seseorang untuk mem- } \\
\text { berikan gift sebanyak-banyaknya pada broadcaster yang disukainya. }\end{array}$ \\
\hline 12 & Banned & $\begin{array}{l}\text { Akun yang di non-aktifkan karena melakukan pelanggaran, dalam waktu yang singkat atau se- } \\
\text { lamanya. Bahasa ini muncul karena sistem Bigo Live yang mengantisipasi adanya pelanggaran } \\
\text { dalam melakukan live broadcast. }\end{array}$ \\
\hline 13 & Pascol & $\begin{array}{l}\text { Singkatan dari pasukan coli, yaitu pengguna Bigo Live yang memiliki level rendah dan sering } \\
\text { berada di room wanita-wanita seksi serta melontarkan komentar-komentar yang menunjukkan } \\
\text { sex oriented. Bahasa ini muncul karena adanya latar belakang pengguna lelaki yang menggu- } \\
\text { nakan Bigo Live untuk melihat wanita-wanita cantik dan menggoda di Bigo Live. }\end{array}$ \\
\hline 14 & Melon & $\begin{array}{l}\text { Sebutan untuk wanita-wanita seksi yang suka memamerkan belahan dadanya. Bahasa ini muncul } \\
\text { karena banyaknya pengguna wanita dengan latar belakang kurang pendidikan, sehingga mereka } \\
\text { mencari uang dengan menggoda dan menggunakan bagian tubuhnya saja tanpa keahlian tertentu. }\end{array}$ \\
\hline 15 & $\begin{array}{l}\text { Laler Ijo/ } \\
\text { Cendol }\end{array}$ & $\begin{array}{l}\text { Pengguna dari level antara 1-5 yang suka mengomentari broadcaster dengan kata-kata yang tidak } \\
\text { dijaga. Bahasa yang khusus digunakan oleh anggota KCM karena banyaknya pengguna dengan } \\
\text { latar belakang kurang berpendidikan, sehingga tidak memiliki etika dan sopan santun. }\end{array}$ \\
\hline 16 & Haters & $\begin{array}{l}\text { Pengguna yang melakukan komentar-komentar dengan kata-kata kasar dan tidak beretika. Baha- } \\
\text { sa ini hampir sama artinya dengan laler ijo/cendol, namun bahasa ini yang biasa digunakan oleh } \\
\text { seluruh pengguna Bigo Live. }\end{array}$ \\
\hline
\end{tabular}

Sumber: Hasil Penelitian, 2017 
pengguna yang aktif menggunakan Bigo Live, sehingga pengguna memunculkan bahasa yang kemudian diingat dan diimitasi oleh viewers. Melalui bahasa dapat dijadikan sebagai suatu simbol. Dan menurut Alif, yang menyepakati bahwa satu sistem simbol dapat dipergunakan untuk saling bertukar pesan untuk mendapatkan kesamaan makna diantara para pelaku komunikasi (Alif, Nasution, \& Rohadji, 2008).

Jika dikaitkan antara teori dan hasil dari wawancara maupun observasi yang dilakukan oleh peneliti, peneliti menganalisis untuk melakukan interaksi sosial, terdapat beberapa faktor yang mendasarinya baik secara tunggal maupun bergabung, faktor tersebut menurut Vide Bonner adalah faktor imitasi, faktor sugesti, faktor identifikasi, dan faktor simpati (Gerungan, 2010). Faktor imitasi yang dilakukan oleh kelima informan meliputi mengikuti berbagai gaya, cara, sapaan, maupun bahasa dari orang lain dalam melakukan live. Faktor sugesti yang dilakukan kelima informan meliputi berperilaku sesuai dengan peraturan Bigo Live dan KCM yang sudah ditetapkan. Sedangkan keempat informan merasa faktor identifikasi tidak mendasari dalam melakukan interaksi sosial, karena mereka tidak menjadikan orang terdekatnya sebagai contoh atau panutan dalam berinteraksi di Bigo Live. Hanya satu informan yang memiliki satu sosok ideal sehingga ingin memiliki cara interaksi seperti sosok tersebut. Sedangkan dalam faktor simpati, kelima informan mengatakan $\mathrm{KCM}$ memiliki faktor simpati yang cukup tinggi antar satu dengan yang lain. Hal ini berupa rasa saling peduli terhadap internal maupun eksternal $\mathrm{KCM}$ yang dilakukan dengan terjun langsung membantu korban bencana alam, memberikan belasungkawa dan prihatin terhadap anggota maupun mantan anggota $\mathrm{KCM}$ yang sedang sakit atau mengalami kecelakaan, saling memberikan semangat dan dukungan dalam melakukan kegiatan sehari-hari, datang dalam acara wisuda anggota $\mathrm{KCM}$, maupun saling peduli terhadap kisah cinta maupun keadaan perasaan orang-orang yang memiliki kedekatan di KCM.

Jika dikaitkan dengan teori interaksionisme simbolik, terdapat interaksi yang maknanya disepakati secara bersama-sama oleh anggota $\mathrm{KCM}$ maupun seluruh pengguna Bigo Live dilihat dari faktor yang mendasari dalam melakukan interaksi. Dari faktor imitasi, terdapat penyebaran cara, gaya, maupun bahasa yang memiliki makna, diantaranya adalah bahasa perangkat dan bahasa baru yang muncul di Bigo Live yang disebut netspeak dan netlingo oleh Rulli Nasrullah. Bahasa dalam tabel di atas merupakan paparan bahasa yang muncul di Bigo Live. Dari faktor sugesti, peneliti menemukan aturan yang disepakati dan disepakati maknanya secara bersama-sama 
oleh anggota KCM, yaitu no fakir, no baper, no drama, julid hanya sekedar hiburan. No fakir berarti tidak boleh meminta kepada viewers, no baper berarti tidak boleh membawa masalah perasaan antar anggota $\mathrm{KCM}$ di dalam group, no drama berarti tidak ada drama yang dilakukan anggota $\mathrm{KCM}$ seperti upaya untuk mendapatkan perhatian, julid hanya sekedar hiburan berarti saling meledek satu sama lain diperbolehkan tetapi hanya sebagai hiburan. Sedangkan dalam faktor simpati, seluruh anggota KCM pernah menunjukkan kepeduliannya terhadap sesama anggota dengan mengganti profile picture Bigo Live menggunakan lukisan wajah salah satu anggota KCM yang bertuliskan \#saveart. Hal itu dilakukan sebagai bentuk demo karena anggota dalam lukisan tersebut di banned hanya karena menggambar hentai yang agak terbuka.

Bigo Live merupakan salah satu media sosial yang berkonten seperti dunia entertainment, di mana setiap konten yang ditampilkan dalam melakukan live sangat menentukan apakah dapat menarik orang untuk menonton dan stay di room tersebut atau tidak. Sehingga tidak aneh jika setiap berusaha menampilkan konten semenarik mungkin dengan penampilan yang baik, seperti menampilkan berbagai bakat, membicarakan sesuatu yang menarik, menghibur orang lain dengan menari, lipsync lagu, atau hanya mengobrol santai namun dengan cara yang komunikatif. Untuk dapat menarik viewers, kelima informan bermain peran dalam live-nya dan melakukam proses pengelolaan kesan agar bisa menampilkan kesan sesuai dengan keinginannya.

Hal ini sesuai dengan teori Dramaturgi menurut Goffman yang mengatakan bahwa setiap individu merupakan seorang aktor yang memainkan peran atau drama teatrikal, sehingga Goffman memandang interaksi sosial yang berlangsung dalam kehidupan merupakan sebuah drama pertunjukkan diatas panggung. Interaksi ini merupakan sebuah proses di mana aktor berusaha memainkan perannya agar apa yang dimaksud oleh aktor tersebut bisa sampai dan memiliki makna yang sama dengan aktoraktor lain (penonton) (Elbadiansyah, 2014).

Dalam memainkan peran dalam kehidupannya, peneliti membaginya menjadi tiga panggung, yaitu front stage dan back stage menurut Goffman, serta middle stage menurut Mulyana, bahwa yang dimaksud dengan front stage merupakan sebuah panggung di mana menunjukkan siapa dirinya kepada penonton, bagaimana konten yang ditampilkannya, dan berbagai aksi yang dilakukan ketika sedang live (Mulyana, 2008). Middle stage merupakan panggung di mana mempersiapkan segalanya agar bisa tampil di depan penonton dan menunjukkan kesan sesuai dengan keinginan tersebut. Sedangkan back stage merupakan panggung di mana viewers tidak mengetahui 
sisi lain yang tidak pernah ditampilkan oleh kepada viewers-nya.

Kelima informan memiliki perannya masing-masing dalam panggung depan, panggung tengah, dan panggung belakang. Informan yang memiliki panggung belakang berbicarajikahanyadiperlukan, moody, danlebih pendiam melakukan proses pengelolaan kesan dengan mendiskusikan konten bersama timnya di panggung tengah sehingga menghasilkan kesan berupa profesional dalam bermain peran, ceria, ramah, banyak berbicara, mudah bergaul, mudah menjalin relasi, dan memiliki tingkat kepedulian terhadap sesama yang tinggi. Informan yang banyak bicara dalam panggung belakang, melakukan proses pengelolaan kesan dengan mengumpulkan informasi, merapikan keadaan sekitar, dan merapikan penampilan diri sehingga menghasilkan kesan berwibawa, kalem, memiliki intelektual yang tinggi, dan sopan. Sedangkan informan yang memiliki panggung belakang yang lebih pendiam dan kaku, melakukan proses pengelolaan kesan dengan berlatih dan mempersiapkan penampilan agar bisa tampil dengan kesan lucu, komunikatif, sopan, dan pintar membawa suasana.

Untuk informan yang sering mengalami stress dan tekanan di panggung belakang, melakukan persiapan peralatan live dan mempersiapkan penampilan di panggung tengah serta menampilkan sisi yang selalu ceria, menghibur, kreatif, komunikatif, dan berintelektual tinggi di panggung depan. Dan untuk informan yang lebih sering berbicara di panggung belakang, melakukan pengelolaan kesan dengan live hanya disaat penampilan sudah terlihat baik dan melakukan make up dengan panggung depan yang terlihat apa adanya, namun tetap komunikatif. Padahal menurut Goffman bahwa individu ketika berinteraksi di ruang virtual membutuhkan sedikit waktu untuk mengelola dan memikirkan tindakan yang harus ia lakukan (Benedictus, 2010).

Bagaimana persiapan anggota $\mathrm{KCM}$ sebelum melakukan live agar bisa melakukan peran dengan menunjukkan kesan yang baik sesuai keinginan berkaitan dengan pendapat Goffman tentang impression management. Dengan demikian, dramaturgi merupakan suatu perspektif sosiologis yang mendeskripsikan tentang diri sang aktor yang secara aktif mencoba untuk membentuk persepsi orang lain dari mereka dengan menghadirkan diri dengan cara memunculkan penampilan atau citra terbaik yang akan membantu mereka mencapai tujuannya tersebut. Diri sang aktor akan bertindak berbeda di depan orang yang berbeda dan dalam lingkungan yang berbeda pula untuk membentuk penampilan atau citra yang terbaik sebagaimana mereka merasakannya 


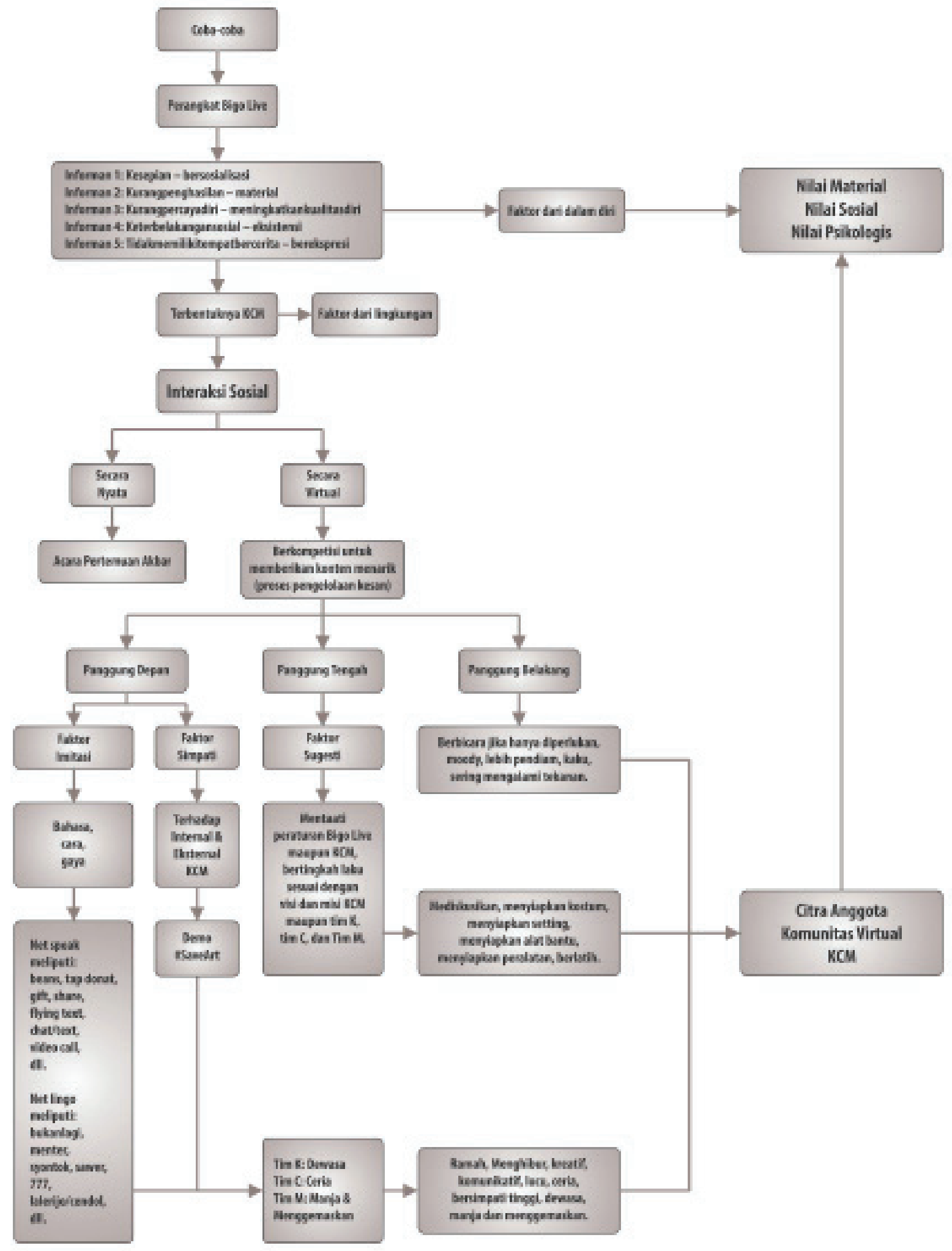

Sumber: Model Hasil Penelitian, 2017

Gambar 1 Model Hasil Penelitian 
(Elbadiansyah, 2014).

Dari permainan peran yang dilakukan oleh anggota $\mathrm{KCM}$, anggota $\mathrm{KCM}$ tersebut membentuk sebuah kesan atau citra yang baik untuk penontonnya, yang mayoritas didasari oleh Visi KCM. Visi KCM merupakan tujuan yang dibentuk bersama-sama oleh setiap anggota dan menjadi dasar setiap anggota dalam bertingkah laku di Bigo Live maupun di media sosial lain. Kesan atau citra tersebut diantaranya ramah, ceria, lucu, komunikatif, mudah bersosialisasi, kreatif, sopan, dewasa, dapat menghibur, dan memiliki rasa kepedulian yang tinggi. Menurut Frank Jefkis citra adalah kesan seseorang atau individu tentang sesuatu yang muncul sebagai hasil dari pengetahuan dan pengalamannya (Soemirat \& Ardianto, 2007). Proses pengelolaan kesan yang dilakukan kelima informan merupakan bentuk interaksi berdasarkan teori impression management Goffman. Artinya bisa dikatakan bahwa diri bukan merupakan situasi yang tetap, tetapi berubah dimana pada tiap interaksi masingmasing pihak harus mendefinisikan situasi yang terjadi sesuai dengan peran yang dimainkannya (Junaedi, 2010).

Siapapun orang yang berada di dunia, menganggapnya pasti menjadi identitas yang berbeda. Jordan dan Tucle mengatakan identitas di dunia merupakan identitas yang hibrid, identitas yang baru, yang selalu menampilkan sesuatu yang baik-baik saja. Dalam back stage pengguna Bigo Live merupakan suatu pertarungan identity di mana tidak banyak orang yang mengetahui identitas asli yang ada dalam diri pengguna Bigo Live tersebut. Namun Nasrullah tidak mempermasalahkan front stage, middle stage, ataupun back stage, tetapi lebih menekankan di luar stage sebagai persoalan (Nasrullah, 2015). Di luar panggung itu orang yang menggunakan Bigo Live cenderung tidak dihargai dalam kehidupan nyatanya, sehingga mereka mencari tempat di mana mereka dapat dihargai dan mendapatkan teman. Hal ini sesuai dengan hasil penelitian dari Pattipeilohy yang menunjukkan bahwa yang paling mempengaruhi citra diri seseorang adalah orang-orang sekitar yang berinteraksi dengan dirinya, karena interaksi tersebutlah yang akan menjadi realita (Pattipeilohy, 2015).

\section{SIMPULAN}

Berdasarkan hasil penelitian tentang interaksi sosial komunitas virtual di Bigo Live yang telah diuraikan dan dianalisa, maka peneliti menarik beberapa kesimpulan. Motif utama para anggota KCM menggunakan Bigo Live berasal dari faktor internal yang berasal dari dalam diri anggota KCM. Motif yang pertama adalah karena kesepian sehingga ingin bersosialisasi. Kedua, karena kurangnya penghasilan sehingga ingin mendapatkan materi. 
Ketiga, karena kurang percaya diri sehingga anggota $\mathrm{KCM}$ tersebut ingin meningkatkan kualitas diri. Keempat, karena keterbelakangan sosial di masa lalu sehingga mereka ingin meningkatkan eksistensi. Dan yang kelima karena tidak memiliki tempat bercerita sehingga ingin berekspresi. Sedangkan terbentuknya komunitas virtual $\mathrm{KCM}$ berasal dari faktor lingkungan di mana sudah banyak komunitas virtual yang lebih dulu muncul serta adanya hubungan yang terjalin dari interaksi sosial di Bigo Live yang mampu mendekatkan individu yang tadinya tidak saling mengenal menjadi akrab. Interaksi yang berlangsung secara terus menerus menimbulkan kesamaan pandangan serta suatu perasaan yang membuat individu ingin mengenal lebih dalam dan lebih dekat dengan individu lainnya. KCM merupakan komunitas virtual dengan nilai kekeluargaan yang memiliki struktur, visi misi yang jelas, serta peraturan yang harus dipatuhi oleh seluruh anggota. Dengan adanya struktur organisasi, berbagai masalah maupun pembuatan kebijakan diselesaikan melalui proses yang terkoordinasi dengan baik

Interaksi sosial yang terjadi dalam komunitas virtual $\mathrm{KCM}$ merupakan interaksi yang dipertemukan karena adanya Bigo Live, kemudian melakukan komunikasi yang lebih intensif melalui group Line, dan untuk lebih mendekatkan lagi dilakukan pertemuan secara langsung agar apa yang selama ini bersifat virtual menjadi lebih nyata. Dari interaksi yang dilakukan tersebut terdapat simbol yang memiliki makna yang disepakati bersama oleh pengguna Bigo Live maupun anggota $\mathrm{KCM}$. Simbol yang didasari oleh imitasi adalah gaya, cara, dan varietas bahasa yang merupakan bahasa perangkat serta bahasa yang muncul dari interaksi sosial. Bahasa tersebut diantaranya: bukan lagi atau bukbuklaglag, menter, syontok, coya, gila gila, sawer, 777, toyong, room, Live, out, raja sawer, banned, pascol, haters, melon, laler ijo/cendol. Simbol yang didasari oleh sugesti berupa aturan no fakir, no baper, no drama, dan just julid. Dan simbol yang didasari oleh simpati adalah \#SaveArt.

Dalam melakukan Live, para anggota KCM melakukan persiapan terlebih dahulu agar dapat menampilkan kesan seperti apa yang diinginkan. Proses pengelolaan kesan yang dilakukan oleh anggota $\mathrm{KCM}$ adalah mediskusikan, menyiapkan kostum, menyiapkan setting, menyiapkan alat bantu seperti backsound, menyiapkan peralatan, dan berlatih. Dari adanya proses pengelolaan kesan dengan berbagai interaksi sosial yang dilakukan anggota $\mathrm{KCM}$ tersebut, anggota $\mathrm{KCM}$ menampilkan konten dengan kesan yang menarik untuk ditonton dan disampaikan kepada viewers saat live. Kesan yang ditunjukkan oleh kelima informan adalah membentuk citra anggota KCM yang baik yang 
didasari oleh visi KCM yang sudah disepakati bersama dan menjadi dasar setiap anggota dalam bertingkah laku. Dari hasil kesepakatan tersebut, anggota $\mathrm{KCM}$ memiliki citra ramah, sopan, komunikatif, dapat membangun suasana, selalu mentaati peraturan yang berlaku, tidak sombong, dapat menghibur, memiliki selera humor yang baik, kompak, dan memiliki kepedulian yang tinggi terhadap sesama. Dengan terbentuknya citra yang baik, maka motif dari anggota $\mathrm{KCM}$ dalam menggunakan Bigo Live dapat terpenuhi, yaitu bersosialisasi, mendapatkan materi, meningkatkan kualitas diri, meningkatkan eksistensi, dan berekspresi.

Dengan menggunakan Bigo Live banyak manfaat yang bisa didapatkan dari hanya sekedar mencari hiburan dengan didasari oleh nafsu semata yang selama ini menjadi persepsi orang-orang yang tidak mengetahui manfaat Bigo Live secara mendalam. Alangkah baiknya menggunakan Bigo Live untuk hal-hal yang positif dengan melakukan penyiaran sesuai peraturan yang sudah ditetapkan oleh Bigo Live agar dapat benar-benar merasakan manfaat dari media sosial ini. Namun harus tetap berhati-hati dalam memilih teman dan menginformasikan keadaan sekitar agar terhindar dari kejahatan.

\section{DAFTAR PUSTAKA}

Alif, M., Nasution, S. H., \& Rohadji, F. (2008). Pengaruh jenis bahasa narasi dan bentuk pesan visual video terhadap peningkatan pengetahuan tentang penyakit Chikungunya pada siswa SMAN 1 Ciampea. Jurnal Komunikasi Pembangunan, 06(1), 1-13. Anwar, Y., \& Adang. (2013). Sosiologi untuk Universitas. Bandung: Refika Aditama.

Arifin, B. S. (2015). Psikologi sosial. Bandung: Pustaka Setia.

Ayutiani, D. N., Primadani, B., \& Putri, S. (2018). Penggunaan akun instagram sebagai media informasi wisata kuliner. Jurnal PRofesi Humas, 3(1), 39-59.

Benedictus, A.S (2010). Konstruksi diri dan pengelolaan kesan pada ruang riil dan ruang virtual. Jurnal ASPIKOM, 1(1), 26-40.

Effendy, O. U. (2001). Ilmu, Teori dan Filsafat Komunikasi. Bandung: Citra Karya.

Elbadiansyah, U. (2014). Interaksionisme simbolik: dari era klasik hingga modern. Jakarta: Rajawali Pers.

Gerungan, W. A. (2010). Psikologi sosial. Bandung: Refika Aditama.

Hine, C. (2001). Virtual ethnography. London: SAGE Publications Inc.

Junaedi, F. (2010). Relasi terorisme dan media. Jurnal ASPIKOM, 1(1), 15-40.

Mulyana, D. (2008). Metode penelitian komunikasi. Bandung: Remaja Rosda Karya.

Nasrullah, R. (2014). Teori dan riset media siber (cybermedia). Jakarta: Kencana Prenada Media.

Nasrullah, R. (2015). Media Sosial. Bandung: Simbiosa Rekatama Media.

Nugraha, A. R., Yustikasari, \& Koswara, A. (2017). Branding kota Bandung di Era Smartcity. Jurnal Ilmu Komunikasi, 8(1), $1-16$.

Pattipeilohy, E. M. (2015). Citra diri dan popularitas artis. Jurnal Kajian Komunikasi, 3(1), 22-32. 
Soemirat, S., \& Ardianto, E. (2007a). Dasardasar public relations. Bandung: Simbiosa Rekatama Media.

Soemirat, S., \& Ardianto, E. (2007b). DasarDasar Public Relations (Satu). Bandung: Remaja Rosda Karya.
Walgito, B. (2011). Teori-teori psikologi sosial. Yogyakarta: Andi Offset.

Zuhdi, N. (2010). Analisis semiotik iklan layanan masyarakat JAMKESMAS. UIN Sunan Ampel. Retrieved from http://digilib. uinsby.ac.id/28974/ 